\title{
子どもの骨盤形態の実態と関連因子の検討
}

\author{
増田 一太 ${ }^{1-3}$
}

\section{Investigation of pelvic deformation and related factors of children}

\section{Kazuto Masuda ${ }^{1-3}$}

\begin{abstract}
The purpose of this study was to clarify the relationship between gender differences in pelvic deformation and physical factors in children. The subjects were 19 boys aged 11 years or younger and 16 girls aged 9 years or younger, allegedly not having puberty. The external pelvimetry values, age and physique were investigated. The degree of pelvic opening and torsion was calculated from the external pelvimetry values. The results showed no gender differences, except that the value corresponding to the distance between ASIS divided by height was significantly higher in girls. The degree of pelvic opening was dependent on the distance of lateral diameter of sacrum. There was no gender difference in the degree of pelvic torsion that causes abnormal delivery and sacroiliac joint pain. In addition, it was found that there was a certain amount of torsion from childhood.
\end{abstract}

Key words : external pelvimetry, pelvic opening, pelvic torsion, children

骨盤外計測，骨盤の開き，骨盤の捻じれ，子ども

\section{I 緒言}

近年の女性の骨盤形態は, 骨盤腔内の前後径が 長い類人猿型が増加（高橋・柳澤，1985；鳴本・ 杉浦，2014）している.この類人猿型の骨盤形態 や骨盤の捻じれなどの形態異常は, 将来的に難産 や帝王切開へのリスクを高め, 分娩の難易度に大 きな影響を及ぼす（鈴木，1959）ことや，仙腸関 節障害を発症（村上，2012）させる可能性を高め るため，男女ともに問題となる現象である。骨盤 形態は, 経年的な身体的ストレスや栄養状態など の環境要因の影響を受ける可能性（Wittman and Wall, 2007 ; LaVelle, 1995）があり, 後天的に変化
する部位であるといえる。この原因については, 加齢や分娩経験が影響する可能性（増田ほか, 2019 ; 潘ほか, 2003）が指摘されているものの, 主に骨盤形態が成熟した後の変形因子の検討に留 まっている. しかし，幼年期から思春期の間にも 影響を受けることが報告（Abitbol, 1988）されて おり，特に骨盤のY 字軟骨が癒合するまでの間に 生じる機械的・生化学的影響が骨盤形態に反映さ れる可能性が高い，骨盤形態の成熟には，骨盤な ど骨の成熟に女性ホルモンが関与し同ホルモンの 分泌により成長ホルモンの分泌が促進される必要 がある．特に月経発来の前年には，骨盤の成長が 長管骨に比べ顕著（大沼，1997）であり，骨盤の

\footnotetext{
国際医学技術専門学校 理学療法学科

立命館大学立命館グローバル・イノベーション研究機構

3 京都工芸繊維大学大学院工芸科学研究科バイオテクノロジー専攻

${ }^{1}$ Department of physical therapy, International institute of medical therapy

${ }^{2}$ Ritsumeikan University Ritsumeikan Global Innovation Research Organization

${ }^{3}$ Department of Applied Biology Kyoto Institute of Technology
} 


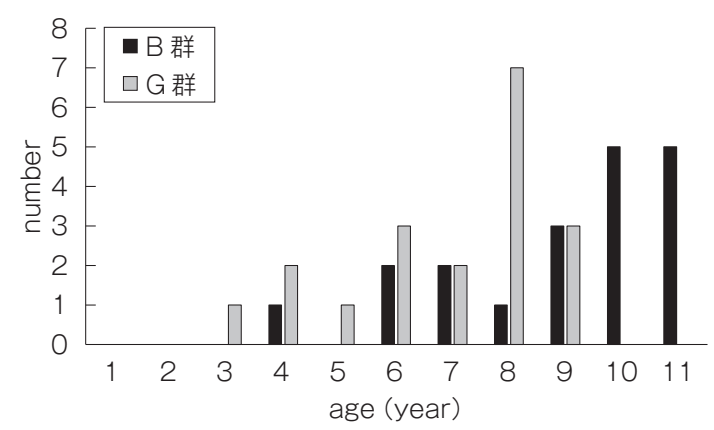

図 1 対象者の年齢の度数分布

発達に強く影響する。 日本人の場合, 男子で 12 歳, 女子で 10 歳（日本小児内分泌学会）より性差 が生じ初め, 男子では 15 歳, 女子では 13 歳まで に $99.6 \%$ が思春期発来し, その後の二次性徵の 3〜5 年後には性成熟が完成（大山，2004）する. これらより, 思春期発来後の数年後には骨盤の外 骨格的成熟はすでに完成を迎え，骨盤形態に性差 が生じている可能性が高い。また，思春期以後の 骨盤形態について渡辺（1961）は, 骨盤の前後径, 左右径ともほぼ同じ比率で増大することを報告し ており, 思春期以降の骨盤形態の比率は大きく変 わらないことが推察できる。 そのため, 思春期発 来前の骨盤への力学的要因が骨盤形態に大きな影 響を及ぼすことが考えられる。

このように，骨盤の形態には男女とも思春期発 来以前の要因が骨盤形態に影響を及ぼす可能性が 高いものの, 同時期の骨盤形態の実態や変形因子 についての検討が十分に行われているとは言い難 い. 骨盤の外骨格的成熟以前の骨盤形態と変形因 子との関係性の調査は, 変形予防の観点からも重 要である。そこで今回，一般的に思春期発来を迎 えておらず，かつ性差が生じていないとされる男 子 11 歳, 女子 9 歳以下までの男女を対象とし, 骨 盤形態の実態と身体的要因の関係について検討し た。

\section{II 対象と方法}

\section{1. 対 象}

対象は 11 歳以下の男子 19 名（平均年齢 $8.9 \pm$ 2.1 歳) (以下, $\mathrm{B}$ 群), 9 歳以下の女子 16 名 (平 均年齢 $7.1 \pm 1.8$ 歳）（以下, $\mathrm{G}$ 群）とした（図 1).

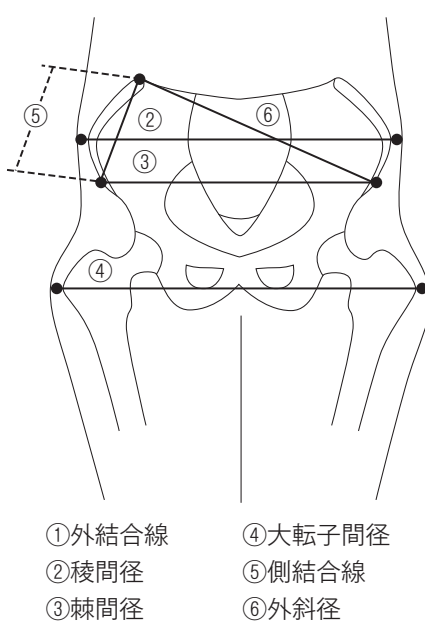

図 2 骨盤外計測法による計測部位 （中西正美 (2001) 15 骨盤計測（研修医の ための必修知識, B 産婦人科検査法), 日本産 科婦人科学会雑誌, 53, 325-333 より転載)

除外基準は, 対象者に腰殿部痛がないこと, 思 春期早症・遅症などのホルモン異常がないこと, 腸骨の形態に明らかな左右差のある対象は, 骨盤 形態の非対称性を検討する上で不適切である。そ のため, 腸骨の上前腸骨棘と上後腸骨極間距離を 表す側結合線を 2 度計測し, その平均值の左右差 が $0.5 \mathrm{~cm}$ 以上ある児童は骨盤の非対称性の原因 が, 腸骨の非対称性由来である可能性が高いため 除外した。

\section{2. 方 法}

\section{1）一般身体情報}

身長, 体重をデジタル身長計 $\left(\mathrm{AD}^{-6} 6400, \mathrm{~A} \& \mathrm{D}\right.$ 社製）にて小数点第一位までの值を計測した。な お計測した身長と体重より Body Mass Index（以 下，BMI）を算出した。

2) 骨盤外計測方法 (図 2) と測定項目

骨盤の測定肢位は, 日本産科婦人科学会が制定 する骨盤外計測法 (中西, 2001) に準じ実施した. 計測項目は, 両側の上前腸骨棘間距離を表す前棘 間径（以下， $\mathrm{AD}$ ), 左上前腸骨棘と右上後腸骨棘 から成る第一斜径 (以下, FOD), 右上前腸骨棘 と左上後腸骨棘から成る第二斜径（以下, SOD) とした。 また両上後腸骨棘間距離を後棘間径（以 下，PD）とした。

計測は Martin 型骨盤計を用い, 測定は 2 回実施 
表 1 男女別一般身体情報と骨盤外計測測定値の各変数

\begin{tabular}{lccl}
\hline & 男子 $(n=19)$ & 女子 $(n=16)$ & 有意確率 \\
\hline 年齢 $($ 歳 $)$ & $8.9 \pm 2.1$ & $7.1 \pm 1.8$ & $p=0.007$ \\
身長 $(\mathrm{cm})$ & $132.1 \pm 14.9$ & $122.7 \pm 36.5$ & $\mathrm{p}=0.34$ \\
体重 $(\mathrm{kg})$ & $31.4 \pm 11.2$ & $29.6 \pm 9.7$ & $\mathrm{p}=0.62$ \\
$\mathrm{BMl}\left(\mathrm{kg} / \mathrm{m}^{2}\right)$ & $17.1 \pm 3.8$ & $16.8 \pm 2.2$ & $\mathrm{p}=0.67$ \\
$\mathrm{AD}(\mathrm{cm})$ & $18.3 \pm 2.7$ & $19.1 \pm 2.4$ & $\mathrm{p}=0.40$ \\
$\mathrm{AD} /$ Height & $13.5 \pm 1.4$ & $14.6 \pm 0.9$ & $\mathrm{p}=0.03$ \\
$\mathrm{PD}(\mathrm{cm})$ & $7.1 \pm 1.2$ & $7.0 \pm 1.5$ & $\mathrm{p}=0.78$ \\
$\mathrm{PD} /$ Height & $5.4 \pm 0.6$ & $5.4 \pm 1.2$ & $\mathrm{p}=0.93$ \\
$\mathrm{PO}$ & $0.39 \pm 0.07$ & $0.36 \pm 0.09$ & $\mathrm{p}=0.24$ \\
$\mathrm{PT}$ & $0.26 \pm 0.35$ & $0.26 \pm 0.24$ & $\mathrm{p}=0.98$ \\
\hline
\end{tabular}

BMI : Body Mass Index

$A D ：$ 前棘間径（両側の上前腸骨棘間距離）

$\mathrm{PD}$ : 後棘間径（両側の後上腸骨棘間距離）

AD/Height：前棘間径を身長にて正規化した值

$\mathrm{PO}$ : 骨盤の開き度（後上腸骨棘間距離を上前腸骨棘間距離で除した值）

PT：骨盤の捻じれ度（第一·二斜径の差の絶対値に対し, 身長にて除した值）

し, 得られた数值を平均化した值を計測值とし, 小数点第一位まで求めた。 なお本計測法の級内相 関係数（ICC）は高く，信頼性は良好である（増 田ほか, 2019).

3 ）計測・問診環境

計測と問診は,プライバシーが確保された個室 で実施した。なお，計測は同一の検者により実施 された。

\section{4) 解析方法}

骨盤の開き度（以下, $\mathrm{PO}$ ) の算出は, $\mathrm{PD}$ を $\mathrm{AD}$ で除した值とし, 骨盤の捻じれ度（以下，PT）の 算出は, FOD と SOD の差の絶対值に対し, 身長 にて正規化した值とした，PO，PT共に小数点第 二位まで求めた. FOD と SODの差が生じない場 合, 骨盤の捻じれ度が存在しないことが考えら れ，逆に両計測值に差が生じる場合は，一側の腸 骨が仙骨に対し前方または後方へ回旋や，一側の 腸骨のみが外転または内転している可能性を反映 し, 数值が大きい程捻じれなどの非対称性が高ま ると考えることができる。また骨盤外計測值の $\mathrm{AD}, \mathrm{PD}$ は，実測值の検討に加え両者を身長にて 除した值を百分率(以下, $\mathrm{AD} /$ Height, $\mathrm{PD} /$ Height) とし, 解析に加えた。

統計は, B 群と $\mathrm{G}$ 群の年齢, 一般身体情報, 各 骨盤外計測值と骨盤の開き值と骨盤の捻じれ值に 対し, 対応のない $\mathrm{t}$ 検定, 性別間の骨盤の捻じれ の発生の有無を検討するため, Fisher の正確確率 検定を実施した。また PO，PT と一般身体情報，
各骨盤外計測值との関係を Pearsonの積率相関係 数にて算出し比較検討した.

これらの調查項目の分析には, SPSS ver23.0 for Windows, IBM 社を用い, 統計的有意水準を $5 \%$ 未満に設定した.

なお，本研究のおける利益相反はない.

\section{III 倫理的配慮}

本研究は, 中部学院大学の倫理審査委員会の承 認（承認番号 D17-0005）を得て実施した。倫理的 配慮として, 被検者と保護者に研究の趣旨, 配慮 (参加・途中辞退の自由, 匿名性の厳守, 研究に限 定したデータの使用), 結果の公表についてを書 面と口頭で説明し，被検者と保護者の両者に同意 を得た対象者に対し計測を行った。

\section{IV 結 果}

一般身体情報と骨盤外計測測定值の各变数の男 女別一覧を表 1, 骨盤外計測值の度数分布を図 3 8 に示す. 今回の検討により年齢は B 群 $8.9 \pm$ 2.1 歳, $\mathrm{G}$ 群 $7.1 \pm 1.8$ 歳（ $\mathrm{p}=0.007 ）$ と有意に男子 が高值を示し, $\mathrm{AD} /$ Height は B 群 $13.5 \pm 1.4, \mathrm{G}$ 群 $14.6 \pm 0.9 \mathrm{~cm} \quad(\mathrm{p}=0.03)$ と有意に女子の方が高值 を示した．その他の変数の男女間の值に有意な差 を認めなかった. また, Fisherの正確検定の結果, 骨盤の捻じれの発生においても性差に偏り $\left(\chi^{2}=\right.$ 


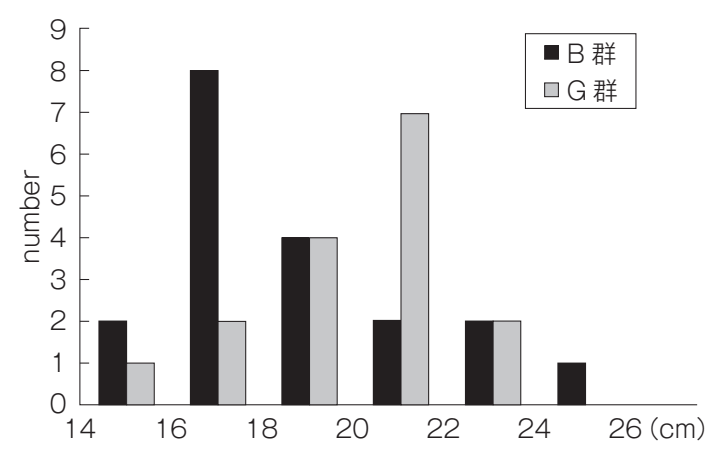

図 3 AD の男女別度数分布

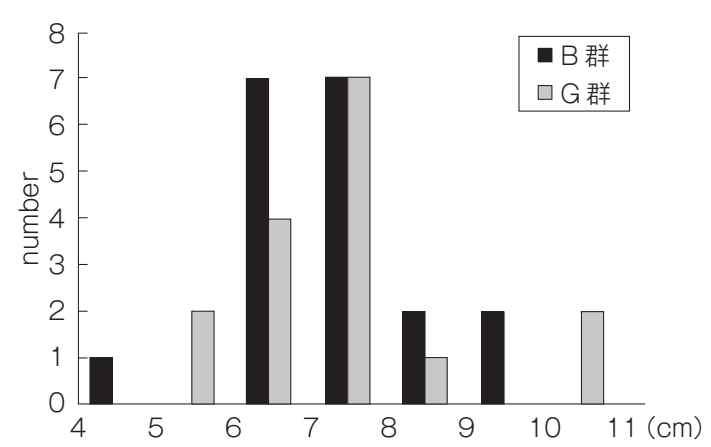

図 5 PD の男女別度数分布

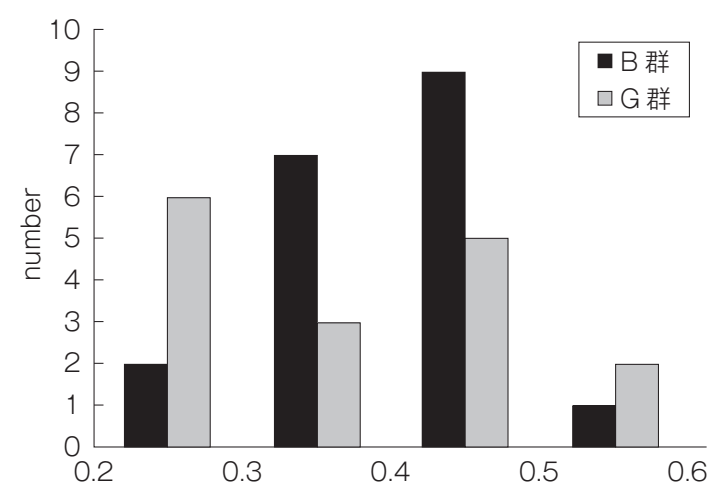

図 7 POの男女別度数分布

0.05, $\mathrm{df}=1, \mathrm{p}=0.83)$ を認めなかった（表 2).

PO と有意な相関間関係を認めた骨盤外計測值 (表 3, 4) は, B 群において $\mathrm{AD} / \operatorname{Height}(\mathrm{r}=-0.71$, $\mathrm{p}<0.01) \operatorname{PD}(\mathrm{r}=0.67, \mathrm{p}<0.01)$, PD/Height $(\mathrm{r}=$ $0.72, \mathrm{p}<0.01), \mathrm{G}$ 群において $\mathrm{PD}(\mathrm{r}=0.88, \mathrm{p}<$ 0.01), PD/Height $(\mathrm{r}=0.83, \mathrm{p}<0.01)$ であった. PT と有意な相関関係を認めた項目は, 両群とも

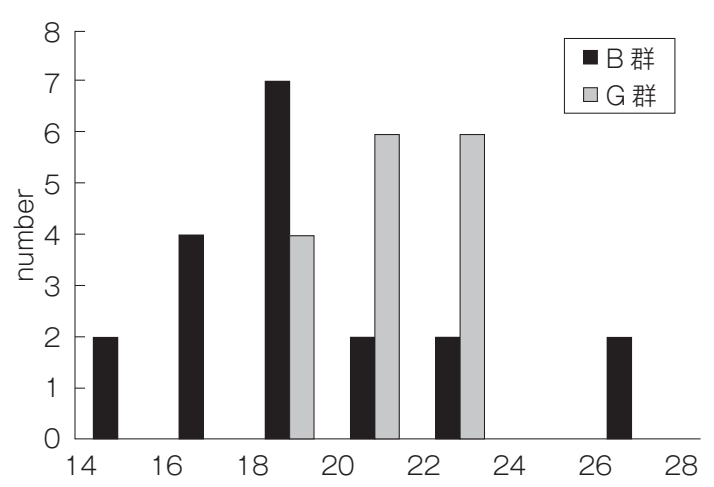

図 4 AD/Height の男女別度数分布

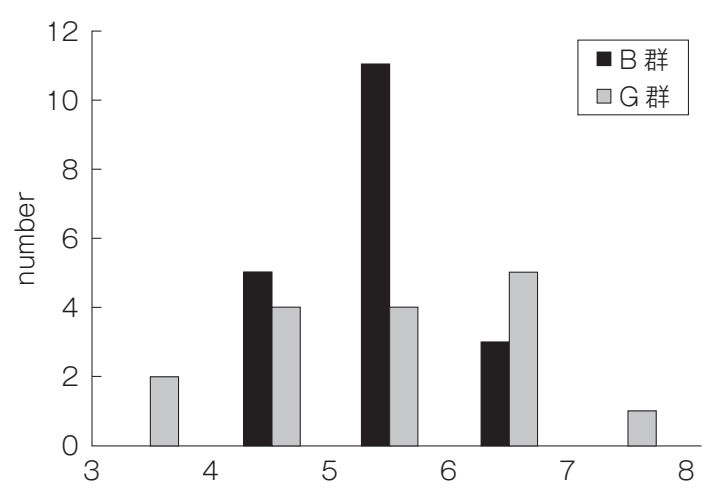

図 6 PD/Height の男女別度数分布

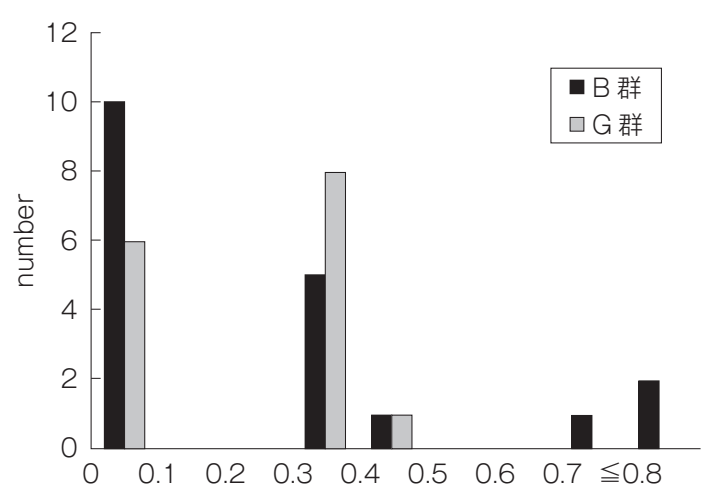

図 8 PT の男女別度数分布

存在しなかった.

\section{$\mathrm{V}$ 考察}

子どもの骨盤外計測值は, 男女とも身長などの 体格同様, 年歯令の推移に従って増大する（荒木, 1985). しかし, 思春期以前の骨盤形態の計測值に 
性差を認めないものの, 思春期以降の女子におい て身長に対する上前腸骨棘間距離にのみに性差が 生じる（大山，2004）とされ，一般的に同時期以

表 2 骨盤の捻じれ発生の性差

\begin{tabular}{crrr}
\hline & \multicolumn{2}{c}{ 性 } & 別 \\
& 男性 & 女性 & 有意確率 \\
\hline 骨盤の捻じれあり & 9 & 10 & $\mathrm{p}=0.67$ \\
骨盤の捻じれなし & 10 & 6 & \\
\hline 合 計 & 19 & 16 & \\
\hline & $\chi^{2}=0.05, d f=1, \quad p=0.83$
\end{tabular}

降に形態的な性差が生じるとされている（大沼, 1997 ; 大山, 2004 ; 荒木, 1985). 本研究結果にお

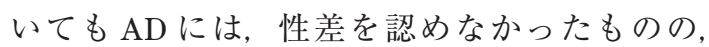
$\mathrm{AD} /$ Height にのみ性差を認め, 大山（2004）の結 果と同様であった， $\mathrm{AD}$ は，上前腸骨棘間距離を 表しており, 同距離の開大は，寛骨の発達により もたらされる，子どもの寛骨の発育について渡辺 （1961）は，身長及び体重との関連性が高く，特に 体重より身長との関連性が高い傾向があることを 報告している。本研究においても $\mathrm{AD}$ は, 男女と も身長・体重と有意な相関を有しており，特に女

表 3 男子における各変数の相関係数

\begin{tabular}{|c|c|c|c|c|c|c|c|c|c|c|}
\hline & 身長 & 体重 & $\mathrm{BMI}$ & 年齢 & $A D$ & AD/Height & PD & PD/Height & PO & PT \\
\hline 身長 & 1.00 & & & & & & & & & \\
\hline 体重 & $0.20 * *$ & 1.00 & & & & & & & & \\
\hline BMl & $0.47^{*}$ & $0.86 * *$ & 1.00 & & & & & & & \\
\hline 年齢 & $0.93^{* *}$ & $0.75^{* *}$ & 0.41 & 1.00 & & & & & & \\
\hline$A D$ & $0.60^{*}$ & $0.79^{* *}$ & $0.75^{*}$ & $0.60^{* *}$ & 1.00 & & & & & \\
\hline AD/Height & -0.29 & 0.13 & 0.41 & -0.21 & $0.59^{* *}$ & 1.00 & & & & \\
\hline PD & $0.68 * *$ & $0.53^{* *}$ & 0.40 & $0.60 * *$ & 0.39 & -0.02 & 1.00 & & & \\
\hline PD/Height & 0.12 & 0.07 & 0.19 & 0.05 & 0.06 & -0.06 & $0.81 * *$ & 1.00 & & \\
\hline $\mathrm{PO}$ & 0.22 & $-0.12^{*}$ & -0.24 & 0.16 & -0.41 & $-0.71^{* *}$ & $0.67^{* *}$ & $0.72^{* *}$ & 1.00 & \\
\hline PT & 0.37 & -0.05 & 0.29 & 0.29 & 0.15 & 0.32 & 0.29 & 0.08 & -0.24 & 1.00 \\
\hline
\end{tabular}

$* * p<0.01 \quad * p<0.05$

$\mathrm{BMI}$ : Body Mass Index

$A D$ : 前棘間径（両側の上前腸骨棘間距離） $\quad A D /$ Height：前棘間径を身長にて正規化した值

$P D$ : 後棘間径（両側の後上腸骨棘間距離） PD/Height：後棘間径を身長にて正規化した值

PO：骨盤の開き度（後上腸骨棘間距離を上前腸骨棘間距離で除した值）

PT : 骨盤の捻じれ度（第一·二斜径の差の絶対値に対し，身長にて除した值）

表 4 女子における各変数の相関係数

\begin{tabular}{|c|c|c|c|c|c|c|c|c|c|c|}
\hline & 身長 & 体重 & BMI & 年齢 & $A D$ & AD/Height & PD & PD/Height & $\mathrm{PO}$ & PT \\
\hline 身長 & 1.00 & & & & & & & & & \\
\hline 体重 & $0.56^{*}$ & 1.00 & & & & & & & & \\
\hline $\mathrm{BMI}$ & 0.28 & $0.74^{* *}$ & 1.00 & & & & & & & \\
\hline 年齢 & 0.44 & $0.76^{* *}$ & 0.22 & 1.00 & & & & & & \\
\hline$A D$ & $0.51^{*}$ & $0.74^{*}$ & 0.22 & $0.89^{* *}$ & 1.00 & & & & & \\
\hline AD/Height & -0.17 & -0.36 & -0.36 & -0.17 & 0.17 & 1.00 & & & & \\
\hline PD & -0.09 & 0.18 & 0.08 & 0.22 & 0.04 & -0.17 & 1.00 & & & \\
\hline PD/Height & -0.47 & -0.41 & -0.16 & -0.40 & $-0.54^{*}$ & 0.02 & $0.77^{* *}$ & 1.00 & & \\
\hline $\mathrm{PO}$ & -0.27 & -0.03 & 0.02 & -0.09 & -0.23 & -0.19 & $0.88^{* *}$ & $0.83^{* *}$ & 1.00 & \\
\hline PT & -0.06 & -0.29 & -0.10 & -0.03 & -0.09 & 0.31 & 0.11 & 0.28 & 0.07 & 1.00 \\
\hline
\end{tabular}

$* * \mathrm{p}<0.01 * \mathrm{p}<0.05$

$\mathrm{BMI}$ : Body Mass Index

$A D$ : 前棘間径（両側の上前腸骨棘間距離） AD/Height：前棘間径を身長にて正規化した值

$P D$ : 後棘間径（両側の後上腸骨棘間距離） PD/Height：後棘間径を身長にて正規化した值

$\mathrm{PO}$ ：骨盤の開き度（後上腸骨棘間距離を上前腸骨棘間距離で除した值）

PT : 骨盤の捻じれ度 (第一・二斜径の差の絶対値に対し, 身長にて除した值) 
子においてその傾向は著明であった。 そのため, 思春期発来以前では, 身長と寛骨の発達の関係性 が男子よりも女子の方が強い（表 3，4）ため，女 子の方が $\mathrm{AD} /$ Height の有意な高值を招いたと考 えられた。これより，思春期発来前にはすでに性 差が生じている可能性が示唆された。一方, PDは 性差を認めなかった。同值は上後腸骨棘間距離, つまり仙骨横径を反映し，成人女性の同径は，性 差を認める部位であるとともに形態的バリエー ションの多い部位である（鈴木, 1959). しかし, 今回の対象年齢が小児期であったため, 同時期に おいて性差が生じていないことが分かった，男子 における PD は, 身長, 体重, 年齢と有意な相関 を認めた。しかし，女子は有意な相関を認める項 目はなかった。これより PD は, 男子において身 体の発達に伴い仙骨横径の発達を認めるものの, 女子では身体的な発達と相関せず，個体差の多い 部位であり, 発達形態に性差を有する可能性が示 唆された。

骨盤外計測值より算出したPO と PT の両者に, 性差を認めなかった。男女ともに, PO と有意な 相関を認めた骨盤外計測值の項目に, PD と PD/ Height がある。これょり, PO は仙骨の横径の個 体差に強く依存することが分かった．PT 值と有 意な相関関係を認めた項目はなく，発育との関係 性よりも個体差の影響が強い可能性がある。ま た，男女の PT 值の性差はないが，小児期より男 女ともに骨盤の捻じれが一定量存在していること が分かった.この值を先行研究 (増田ほか, 2019) より得られた成人未産婦の PT 值が 0.33 と, G 群 のPT值と比較すると高值であった。これより，骨 盤の捻じれは経年的に増強していく可能性が示唆 された，鈴木（1959）は，骨盤形態は 10 歳までは 性差は少ないが, 同時期に骨盤に生じる力学的因 子が骨盤形成に影響を及ぼすことを報告してい る. そのため, 本研究の対象年齢帯では骨盤形態 の実測值に性差を認めなかったが，これ以降のホ ルモンの影響や運動負荷の違いに伴い成熟してい くことが考えられた。

\section{VI 本研究の限界}

本調查は横断的研究であるため, 特に骨盤外計
測值と年齢との間の経年的な変化についてを論じ ることには一定の限界が存在する.

\section{VII 結 論}

今回の検討により, 骨盤外計測值の実測值や PO PT に性差を認めなかった. POへの影響因 子として, 仙骨の横径の影響を強く受けることが 分かった. また, PTの性差を認めなかったもの の, 思春期発来以前より一定の骨盤の捻じれが存 在していることが分かった.

謝辞

本研究にご指導いただきました, 京都工芸繊維大学 基盤科学系教授野村照夫先生, 准教授来田宣幸先生, 立命館大学スポーツ健康科学部教授塩澤成弘先生, ご 参加いただきました対象者の皆様に深く感謝申し上 げます。

\section{文献}

Abitbol, M. M. (1988) Evolution of the ischial spine and of the pelvic floor in the Hominoidea, Am J Phys Anthropol, 75, 53-67

荒木日出之助（1985）小児 - 思春期の女子骨盤発育調 節因子, 日本産科婦人科学会雑誌, 37, 14251426

LaVelle, M. (1995) Natural selection and developmental sexual variation in the human pelvis, Am J Phys Anthropol, 98, 59-72

増田一太, 笠野由布子, 西野雄大, 野中雄太, 河田龍 人（2019）女性の骨盤形態と変形因子の検討一経 腟分婏が与える影響一, 理学療法ジャーナル, 53, 627-632

村上栄一（2012）仙腸関節の痛み一診断のつかない腰 痛一, 南江堂, 25-31

鳴本敬一郎, 杉浦基（2014）日本人女性の骨盤形態は 変化してきているのか? 一骨盤形態に関する 研究の道のり一, 助産雑誌, $68,132-136$

日本小児内分泌学会: 思春期早発症とは?, http:// jspe.umin.jp/public/sishunnki.html（参照日： 2020 年 1 月 27 日)

大沼靖彦（1997）女性骨盤の発育と性機能成熟との関 係について, 日本産科婦人科学会雑誌, 29 , 1065-1073 
大山建司（2004）思春期の発現, Yamanashi Nursing Journal, 3, 3-8

中西正美 (2001) 研修医のための必修知識 B, 産婦人 科検査法 15 骨盤計測, 日本産科婦人科学会雑誌, 53, 325-333

潘宣超, 高山景範, 柴田靖章, 伊藤博元 (2003) CT 解析による本邦成人仙腸関節の形態, Journal of Nippon Medical School, 70, 416-421

鈴木博（1959）分娩に及ぼす骨盤形態異常の影響に就 いて主として仙骨異常について, 日本産科婦人 科学会雑誌, 11, 1999-2008
高橋尚彦, 柳澤隆（1985）近年の妊婦骨盤形態の特徴 について一20 年前との比較検討一, 母性衛生, 26, 269-274

渡辺鑑江 (1961) 発育に伴なう骨盤腔形態変化のレ線 学的研究, 民族衛生, 27, 130-158

Wittman, A. B. and Wall, L. L. (2007) The evolutionary origins of obstructed labor : Bipedalism, encephalization, and the human obstetric dilemma, Obstet Gynecol Surv, 62, 739-748

(受付 : 2019 年 11 月 9 日, 受理 : 2020 年 4 月 22 日)

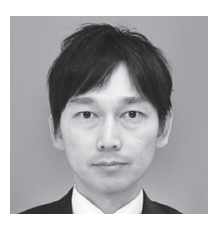

増田 一太（ますだ かずと）

現職：国際医学技術専門学校専任教員
立命館大学大学院スポーツ健康科学修了. 理学療法士. 臨床で問題となる子どもの健康について研究を行ってい る. 近年は, 子どもの腰痛や骨盤形態を調査している. 